CATALAN REVIEW

Catalan Review

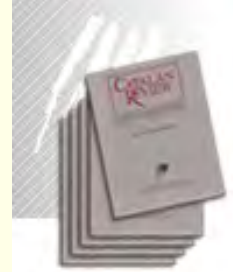

You are accessing the Digital Archive of the Catalan Review Journal.

By accessing and/or using this Digital Archive, you accept and agree to abide by the Terms and Conditions of Use available at http://www.nacs-

catalanstudies.org/catalan review.html

Catalan Review is the premier international scholarly journal devoted to all aspects of Catalan culture. By Catalan culture is understood all manifestations of intellectual and artistic life produced in the Catalan language or in the geographical areas where Catalan is spoken. Catalan Review has been in publication since 1986 .
NORTH

AMERICAN

CATALAN

SOCIETY
Esteu accedint a l'Arxiu Digital del Catalan Review

A l' accedir i / o utilitzar aquest Arxiu Digital, vostè accepta i es compromet a complir els termes i condicions d'ús disponibles a http://www.nacs-

catalanstudies.org/catalan review.html

Catalan Review és la primera revista internacional dedicada a tots els aspectes de la cultura catalana. Per la cultura catalana s'entén totes les manifestacions de la vida intel lectual i artística produïda en llengua catalana o en les zones geogràfiques on es parla català. Catalan Review es publica des de 1986.

\title{
Language, Culture, and Nationality: The case of Jordi Soler Mryellen Bieder
}

Catalan Review, Vol. XXI, (2007), p. 381 -394 


\section{LANGUAGE, CULTURE, AND NATIONALITY: THE CASE OF JORDI SOLER}

\section{MARYELLEN BIEDER}

SOLER, Jordi. Los rojos de ultra mar. 2004. $2^{\text {nd }}$ ed. Madrid: Santillana, 2005. 237 PP.

SOLER, Jordi. La última hora del último día. Barcelona: RBA Libros, 2007. 219 PP.

Catalan literature's status as Guest of Honor at the 2007 Fira de Frankfurt, dubbed a "macroencuentro" by the press (Barranco), brought to the forefront of national debate the conflictive responses linking the Catalan language with Catalan identity. Leaving aside the politically charged relationship between language and state, the polemic boils down to a core question: is language the primary marker of cultural identity or can a culture find legitimate expression in more than one language? At the recent Frankfurt Book Fair, Catalan culture, through its representative body, the Ramon Llull Institute, chose to present one answer, although it simultaneously appropriated the voices of Barcelona-born Castilian-language authors, among them Juan Goytisolo and Eduardo Mendoza, and Madrid-born Jorge Semprún, who publishes predominantly in French. Commenting in El Pais on the Frankfurt Fair, Xavier Vidal-Folch reminded his readers of an axiom echoed repeatedly in Frankfurt: "el mundo literario catalán (ya no el, más amplio, cultural) es sólo el escrito en lengua catalana." While Vidal-Folch attributes the dominance of this "convención mayoritariamente asumida" to the practices of the academic world, Mario Santana, among others, has convincingly challenged the assumption in a breakthrough 2000 article on "national literatures." Vidal-Folch, acknowledging the falsity of the "pretendida pureza de sangre lingüística de esta cultura," affirms instead Catalan culture's "carácter mestizo y plural."

Two recent novels by the Mexican-born author, Jordi Soler, confront, both directly and indirectly, issues of language, culture, nationality, and historical memory that circulated widely in response to Catalonia's prominence in Frankfurt. The first, Los rojos de ultramar (2004), marks his initial contribution to the "memory boom" of recent fiction and films that memorialize the civil war (Labanyi 106). The novel fires its opening salvo in the "memory war," to adopt Jo Labanyi's insightful shorthand for the conflicting versions of historical memory of the Spanish Civil War (97), when the narrator, a professor of 
anthropology from the Universidad Nacional de México, addresses a class at the Universidad Complutense de Madrid. Astounded to discover that Spain's pacto de silencio has produced a generation of students who have no memory of or interest in Spain's past, he reacts as the grandson of a Republican soldier: "sintiéndome un poco ofendido de que el exilio republicano hubiera sido extirpado de la historia oficial de España" (Los rojos de ultramar 16 ). ${ }^{\mathrm{T}}$ When he surveys the beach at Argelès-sur-Mer that once housed the vast concentration camp imprisoning Republican exiles, he reformulates this unwelcome insight: "en esa playa y en aquella aula había la misma voluntad de olvidar ese pasado oscuro y, en realidad, nada remoto" (I83). The narrative is his answer to the revelation that "apenas queda memoria de la guerra" (234) in Spain, or in France, as a result of "el acuerdo colectivo de olvidar" (235).

In contrast to the Spanish students, for Soler's narrator growing up in Mexico the war was a constant, if unspoken, presence in his life that, as he is aware, shapes his worldview: "La manera en que esa condición omnipresente de haber heredado una guerra perdida había interferido en nuestra forma de mirar el mundo" (175). The novel charts his attempt to recover the history of grandfather Arcadi from Republican soldier to Mexican exile to successful businessman to self-exiled hermit. In the process he seeks to understand the grip Catalan language and culture held on his grandfather throughout his life in Mexico and the pull it continues to exert on him. Completed after his grandfather's death, the narrative is an act of "postmemory," as Marianne Hirsch defines the term with reference to the Holocaust, that is, "the effort to maintain the visceral, affective, and ethical response" to history "in the face of the loss of the primary bearers of memory" (20). In a recent article on film and fiction that treat the Spanish Civil War, Labanyi draws a valuable distinction between those novels that employ the "trope of haunting" and those that take a "documentary stance" to attain "maximum verisimilitude" (97, 103). I will argue that Soler's two latest novels, while adding a new dimension to the current memory boom, incorporate features of both groups without falling fully within either.

The lives of Jordi Soler and his unnamed narrator(s) contradict Quim Monzó's pertinent observation that "mucha gente tiene del mundo una idea hecha a partir de la geometría actual del poder político-cultural." At a roundtable discussion infelicitously entitled "Iberoamérica: ‘local, global o glocal?" at the VivAmérica Festival in Madrid in October 2007 , Soler contested being pigeonholed by his early publishers as a "Latin American author," considering the label too

' All quotations from Soler's novels are taken from Los rojos de sltramar, unless otherwise indicated. 
restrictive. The author blurb for both novels locates his birthplace, which is also that of his narrator/protagonist, as the Mexican outpost of La Portuguesa, "una extraña comunidad de blancos que hablaban catalán en medio de una selva que había sido territorio indígena desde hacía milenios" (194). The name of the community, La Portuguesa, once that of a store established by an early Portuguese settler, constitutes a constant reminder throughout the two novels of the persistence of cultural identity across national spaces; it thereby doubly underscores the Catalan refugees' cultural and linguistic separateness. Founded in 1946 by Arcadi and four other Catalan Republican exiles as a coffee plantation hacked from the surrounding jungle, $\mathrm{La}$ Portuguesa survives as a multi-generational, Catalan-speaking enclave which, thanks to the Catalans' entrepreneurial spirit and cultural affinity for work, becomes a financial success, further setting the refugees apart from their neighbors within this multi-cultural, multi-lingual world. ${ }^{2}$ In the "premodernidad" of the selva (55), the Catalans install not only a modern community in miniature but their replica of middle-class Barcelona. In his review of Soler's second novel which expands upon life in $\mathrm{La}$ Portuguesa, La última tarde del último día (2007), Joaquín Marco correctly calls attention to the author's "falso autobiografismo," his tendency to represent his imagined fictional world as his personal history. Soler, throughout his interview with Ima Sanchís in La Vanguardia, and elsewhere, responds as though he and the narrator of La última hora del último día were indistinguishable, thus conflating novel and autobiography.

From the founding of the coffee plantation, the defining characteristic of La Portuguesa is the Catalan identity of its inhabitants manifest in the Catalan language cojoined to classic icons of Catalan culture: its food, its flag and its football allegiance to Barça. The two novels narrate the tension between colonizers-Catalans following in the footsteps of Hernán Cortés and successive waves of Spaniards and other European immigrants-and colonized in terms of cultural clichés: "el ritmo trepidante de los cinco catalanes" set against "el compás relajado con que se trabaja en el trópico" (I93). At different points in both works the underlying cultural conflict provokes a reversal of the polarity of the powerful and the powerless. ${ }^{3}$ Soler assigns the five plantation owners varying degrees of the contrasting threads

${ }^{2}$ The name Arcadi literalizes the arcadian nature of the exiles' enterprise, whether or not it is an example of authorial poetic license.

${ }^{3}$ In interviews, Soler stresses the second-class, if not third-class, status of his grandfather and the other founders of La Portuguesa who had to make their own way in Mexico without the attention and support received by prominent intellecruals, artists, and highranking military officers in exile in the same country (DeMicheli, Pérez Andújar, etc.). 
comprising the Catalan national character, as well as their own personal demons and mechanisms for coping with the loss of culture and country. ${ }^{4}$ Giving voice to the narrator of La última bora del último dia, Soler has remarked regarding the success of the coffee plantation: "En I5 años consiguieron más terrenos y dinero que todos los que los rodeaban" (Sanchís). Although time, climate and geography ultimately defeat the Catalan exiles, as does self-destructive behavior, they successfully replicate the iconic presence of Catalan culture-especially in their persistent use of the Catalan language-in the bug-infested, malaria-transmitting, untamable Veracruzan jungle. In the end, the cultural island that is the Catalan community proves unsustainable, its land under constant encroachment from the selva, a trope for the surrounding cultures that press in upon it. A lone elephant, a circus escapee "que aprovechaba el caos para declarar su independencia" (6I), constitutes an even more starkly absurd dweller on Mexican territory than the Catalan coffee growers. Finally deprived of the selva on which it depends, it becomes Soler's metaphor for displaced men living narrowly constructed, artificial lives in an unwelcoming environment.

The organizing metaphor that centers Soler's second novel, $\mathrm{La}$ última hora del último dia, is the narrator's aunt Marianne, the exoric, ferocious, damaged, and victimized first-born of La Portuguesa. As a trope for the excesses and degeneration of the community she seems both overdetermined and more improbable than the elephant that haunts both novels. Soler has spoken of Marianne as "una metáfora del futuro de aquellos exiliados" (Sanchís). As he structures his novel, her fate, prefigured from the early pages and in the title, is what makes inevitable the ultimate failure of both the plantation, which slowly recedes into the devouring jungle, and the lives of its individual founders. Elaborating on Marianne's function in the novel, Soler proffers this somewhat reductive interpretation: "Su final es una metáfora de esa esencia irreconciliable entre el mundo prehispánico y el hispánico." He thus attributes the disintegration of the Catalan exiles' enterprise to the forces of History, rather than to the aftermath of the Spanish Civil War or to their difficulty in negotiating the loss of culture, history, geography, and, as we will see, language.

4 A recent enumeration of quintessential Catalan characteristics includes the following: "El carácter catalán (me remito a los archivos) 'es realista, práctico, sensato, comprensivo, intuitivo, genialoide, y con un gran sentido común en sus actividades diarias, pero también llega a ser, en determinadas ocasiones, idealista en exceso, excéntrico sin remedio, capaz de apostarlo todo a cara o cruz, buscando ser grande y sufriendo de ser un país pequeño" (Amat).

-5 It is curious to note that Ramón María del Valle-Inclán's alter ego, who fuses with the Galician author in his "Autobiografía," lands at Veracruz, where one of his forefathers had established a colony named for his homeland: the Reino de la Nueva Galicia. 
The question both novels leave unresolved is what identity to assign to a Catalan-named and Catalan-speaking author, born in $\mathrm{La}$ Portuguesa, of Mexican nationality, who writes and publishes in Spanish. Interviewers, critics, and publishers have tended to categorize him as a Mexican writer. His two most recent novels, with their revelation of the idiosyncratic linguistic and cultural space of $\mathrm{La}$ Portuguesa, put this equation in doubt, as does the author himself. In an interview Soler clarifies his linguistic formation and preferences: "Nací hablando dos lenguas en la Cataluña de ultramar" (Mora). As for writing in Castilian, he has declared: "No escribo en catalán porque mi lengua de escritor es el español. He recuperado el catalán..." (DeMicheli). Marco, in his review of La última hora del último dia, confirms Soler's "mestizaje múltiple," identifying him as "este escritor mexicano-catalán-español de vocación irlandesa, en primera línea de los novelistas de la memoria." Elsewhere Soler confesses, in an echo of Arcadi's painful confrontation with the fluidity of language: "Tinc un català d'ultramar" (Piquer). Nevertheless, he keeps alive the multi-generational transmission of the Catalan language, fulfilling "una vieja ilusión," on a return visit to Mexico from his new home in Barcelona, by conversing in Catalan with his son and his grandfather (Mora). The Barcelona-based writer Nùria Amat formulates a question that applies as well to Soler's linguistic situation: " $₫$ En qué idioma escriben o escribimos estos escritores sin tierra, que nos presentan como castellanos en Cataluña y catalanes en todas partes?" $\mathrm{Her}$ answer embraces the language in which Soler writes: "Un castellano naturalmente periférico." The grandson of a Catalan exile, whose military photograph appears on the cover of Los rojos de ultramar, Jordi Soler, like his narrator, is a mestizo in a country of mestizos: a Catalan-speaking Mexican who inherits not only the memory of the war but the mini-nation of $\mathrm{La}$ Portuguesa.

The narrator of both novels, whose namelessness facilitates his assimilation with the author, also speaks Catalan. Although the narrator is a criollo on his father's side, Soler concerns himself with cultural mestizaje, both in the Catalans' resistance to cultural contamination and simultaneously in its inevitable penetration of all aspects of the conflict between cultures. In La última hora del último dia, Soler elaborates on episodes of cultural mestizaje, especially in the relations between Catalans and the ñanga, and the narrator's encounters with an Indian chamana who cures an eye disease that European ophthalmologists cannot; nevertheless, at the same time he dramatizes the mestizos as the primary agents of destruction. The Catalans of $\mathrm{La}$ Portuguesa remain aliens to all their neighbors: Mexicans, Indians, and the "gachupinada de Galatea," pro-Franco 
Spaniards living in the nearby town since before the Spanish Civil War. For the Catalans, fear is primordial, as the narrator of the second novel details: "en La Portuguesa teníamos miedos más arraigados [than fear of an enraged elephant], más clásicos, como el miedo a la invasión, o a la expulsión, o a la revuelta indígena, el miedo a quedarnos otra vez sin nada, otra vez sin país, el miedo a purgar un segundo exilio" (La última hora del último día 106). Only the mutually interdependent ñanga and Catalans share the foreshortened timespan of their usurpation of Mexican territory. Against the backdrop of History, both communities are recent arrivals, in Soler's words, "invasores efímeros" (Sanchís).

Arcadi disengages himself from the "memory war" by professing that "aquélla era la guerra de otro" ( 19, passim). Despite his grandfather's relative silence about the Civil War, the narrator recognizes the war as his ineluctable legacy: "esa historia de guerra" which, almost since his arrival in Mexico, Arcadi "había comenzado a heredarnos" (II). 6 The external manifestation of this legacy is the daily use of the Catalan language at La Portuguesa, although Soler does not specify the family dynamics of how the narrator inherited his grandparents' language.? The narrator declares his mother, born in Barcelona but raised from 1943 in Mexico, perfectly bilingual: "hablaba un catalán canónico y un español mexicano perfecto" (195). He assumes his grandfather's Catalan and his mother's bilingualism, despite the fact that his father, barely mentioned in either novel, is Mexican: "un abogado de buena familia, es decir, una familia mexicana donde no había indios" ( 53 ). The narrator's split identity centers on this language dichotomy. On the one hand, he asserts that he and his brother lack the markers of a bourgeois Barcelona childhood: "Joan y yo éramos mexicanos y punto, habíamos nacido ahí, en la plantación de café, nunca fuimos ni al colegio Madrid ni al Luis Vives, ni al Orfeó Català..." (46). On the other hand, the tension of living between two cultures and two languages is irreducible: "Vivíamos una vida mexicana y sin embargo hablábamos en catalán y comíamos fuet, butifarra, mongetes y panellets, y los is de septiembre, el día de la independencia, permanecíamos encerrados en casa... "(46). Speaking as his narrator, Soler expands on the dual marginalization of Catalans in this symbolic

6 The narrator contradicts himself at different points throughout the narrative regarding the degree to which Spain-and more specifically, Barcelona-constitured part of daily life in La Portuguesa. For example, he observes elsewhere: "Aun cuando no se podía regresar a España, aquella ciudad se nos presentaba como el objeto de deseo, que era semanalmente espoleado con los paseos por las Ramblas que Arcadi proyectaba sobre el tapiz verde del salón..." (67).

- 7 The oral nature of this oral transmission across generations recalls Carme Riera's frequent references to her Mallorcan grandmother's storytelling that inspires and grounds her fiction. 
manifestation of the conflict between dominant and dependent cultures: "El día de la Independencia de México no podíamos salir de casa porque la tradición era moler a palos a los gachupines, léase, españoles, reléase, catalanes" (Sanchís). In La última tarde del último dia, Soler reworks the icons of Catalan national identity displayed in $\mathrm{La}$ Portuguesa and delimits them to popular culture: "como tampoco nos podíamos sentir españoles porque habíamos perdido la guerra, nuestras señas de identidad eran el Barça y las canciones de Serrat. Vivíamos imaginando las jugadas de Cruyff" (Sanchís). ${ }^{8}$

If for Arcadi the Civil War, Catalonia and the Catalan language transform themselves first into memory and then into alienation, the narrator/grandson inherits these memories as his own: "mi Argelèssur-Mer era el que me había heredado Arcadi, no era un territorio físico sino un recuerdo, una memoria con más de sesenta años de antigüedad" (98). Despite the common language bond, historical memory both isolates grandson and grandfather and subsequently brings them into contact as the narrator begins to reconstruct Arcadi's past. When he escaped from occupied France disguised as a member of the Mexican diplomatic mission, Arcadi's Catalan accent represented a risk to his assumed identity: "un diplomático mexicano que hablaba así constituía toda una irregularidad" (169). The requisite muteness that made possible his masquerade anticipates the strategy of silence he later adopts: "En la casa de La Portuguesa nunca se hablaba ni de la guerra ni de España, o más bien, no se hablaba como se debía de ese país donde había algo que era nuestro ni de esa guerra que había hecho pedazos la vida de la familia" (46). The annual telephone call to family in Barcelona and the family dinner, rituals of Christmas Day, in 1963 mark the point, following on the heels of Franco's declaration in 1962 of "veinticinco años de paz," at which Arcadi, faced with two incompatible worlds at his table, "había empezado a formularse esa idea de que otro, y no él, había peleado la Guerra Civil" (2ro). Silence and the simulacrum of communication converge; time and physical distance lend irreality to one's former life, sundering the self in a way that only language can apparently bridge.

When the narrator of Los rojos de ultramar sets out in 1995 to recover Arcadi's silenced history and thereby claim his own inheritance, he constructs his narrative from multiple sources: the memoir Arcadi originally wrote for his daughter shortly after arriving alone in Mexico, tape recordings of the narrator's frustrated interviews with his

B Speaking with the voice of his narrator, Soler adds clothing to the iconic representation of Catalan culture in the Mexican jungle: "Nos vestian con los trajecitos de tergal que enviaban familiares." In his opinion: "Aquel empeño por no entregarnos a la selva era ridículo" (Sanchís). 
grandfather, the archives of the Mexican embassy in Paris, interviews, and his own memories. In these efforts to reclaim the past, the narrator's documentation of Arcadi's experiences aligns with what Labanyi labels a "docufable (fictionalized documentary) format" (I05). ${ }^{2}$ Arcadi's two narratives, the written memoir and the oral tapes-both in Catalan, one can only assume-form the basis for the narrator's first-person narrative. Without writing in Catalan, Soler and his narrator create a world premised on the persistence of the Catalan language. Noting the inclusion of isolated words and phrases in Catalan in La última tarde del último dia, Marco opines that the author, "[p]ara acentuar el verismo de los diálogos introduce frases en catalán." When Arcadi says to his grandson, at their last meeting before his death, "Mira que eres necio, nen" (235), there are two ways to read the novel's penultimate sentence. Either nen signals that Arcadi is speaking to his grandson in Catalan, or the use of a single Catalan word suggests that in his self-imposed isolation and amidst the collapse of the once-successful plantation, even Arcadi's Catalan has given way, surviving only in the affectionate nen.

Arcadi breaks his Mexican exile only in 1970 when he travels to Argelès-sur-Mer without, however, informing his family. Unable to set foot in Catalonia, he visually devours his native countryside from the closest point possible in the French Pyrenees. The narrator captures the full intensity of Arcadi's unspoken passion for his country: "el campo catalán que Arcadi quería hasta el extremo de habernos engañado a todos" (I89). At this point, the rupture between Arcadi's present and his pre-exile existence takes palpable form, manifesting itself in his own pacto de silencio, a silence the narrator seeks to penetrate and reconstruct. Languages naturally change and evolve over time, both within their original territory and when displaced from it. When Arcadi finally returns to Barcelona two years after Franco's death he confronts a reality that challenges his very sense of self: the language he speaks is no longer his native Catalan, but an admixture of Veracruzan Mexican Spanish and 1930s Catalan: "el golpe definitivo, al parecer, se lo dio la lengua, el catalán que había preservado y que había transmitido a dos generaciones, era una lengua contaminada, híbrida, con un notorio acento de ultramar" (228). This sudden realization provokes a profoundly disturbing response in Arcadi that the narrator characterizes as his "capitulación," "retirada,"

${ }^{9}$ Labanyi characterizes Javier Cercas's Los soldados de Salamina as an example of a docufable. The cover photograph of Jordi Soler's grandfather on Los rojos de ultramar and the narrator's emphasis on documentation and research play into this format. However, that which cannor be expressed, the war and the loss that accompanies it, haunts the exiles and their descendants, shaping the trope of haunting, as do the elephant and, in the second novel the role of the chamana and Marianne. 
and "derrota" (234). To borrow Joan Ramon Resina's phrase, Arcadi experiences, in one giant "batzegada" from 1939 to 1977 , the radical transformation of Barcelona: "Les poques persones que encara poden recordar el període republicà saben que literalment han canviat de país."'o The ideal of cultural immutability-the preservation of an unadulterated Catalan culture and language-gives way to Arcadi's and the narrator's awareness of their cultural and linguistic hybridization.

Speaking as his narrator, Soler clarifies in an interview on $\mathrm{La}$ última hora del último día that "[e]n la plantación se hablaba catalán, un catalán muy mestizo, eso nos alejaba de los mexicanos" (Sanchís), but in Los rojos de ultramar Arcadi becomes cognizant of his adulterated Catalan only when circumstances force him to do so when he revisits Barcelona. The microcosm of Republican Catalonia in a Mexican jungle initiates its final dissolution when Arcadi has to face up to the artificiality of the language and culture that he, his associates, and their extended families have kept alive. The Catalan language persists simultaneously in memory and in its contaminated form in the present of $\mathrm{La}$ Portuguesa. However, the dismemberment of the community and the abandonment of the Catalan language begin as early as 1960 when the first grandchildren, "los hijos mexicanos de los exiliados catalanes" (196), leave La Portuguesa for immersion in Spanish at the university in Monterrey or Mexico City. They subsequently engender "los primeros nietos, una prole de criaturas mestizas," among them, the narrator (200).

In contrast to the largely unrepresented Catalan language that defines the spatial boundaries of $\mathrm{La}$ Portuguesa, in his two novels Soler employs a complex and varied linguistic range, a "riquísimo y exótico vocabulario," as Marco phrases it. The exotic otherness of the environment and its unmistakably alien character take on visible contours in the fog of exhaled smoke enveloping all members of the community as they attempt to protect themselves from the hoards of invading insects by smoking puros: "Hombres, mujeres y niños, en cuanto se encendía la luz eléctrica, nos defendíamos a fuerza de humo de los escuadrones de insectos que volaban, brincaban, corrían o se arrastraban" (44). The enumeration of the exuberant local insect life gives another signal of the cultural distance between $\mathrm{La}$ Portuguesa and Barcelona: "También volaban alrededor de la luz eléctrica polillas, mayates, cigarrones, catarinas y campamochas, y ocasionalmente,

10. Speaking of his own grandfather's return to Spain from Mexico, Soler recounts that "sólo aguantó quince días" in Barcelona before retreating to Mexico: "no reconoció la ciudad, ni siquiera el edificio en que habia vivido; hablaba un catalán de ultramar mezclado con castellano y con lenguas indigenas, que no entendian en Barcelona" (Mora). 
dependiendo de la densidad de las evaporaciones de la selva, cocuyos, unicornios y chicharras, aunque estas últimas, como ya se dijo, preferían la seducción del proyector de filminas" (50). Soler's creation of a compelling and improbable narrative universe manifests itself in detailed depictions of the multifarious forms of flora, fauna, and local culture, as well as in the incongruous presence in both novels of an elephant, the increasingly lunatic scheme to kill Franco, and, in $\mathrm{La}$ última hora del último día, the introduction of a new and troubled character, Marianne.

The plot to kill Franco, a significant thread in Los rojos de ultramar that the second novel dramatizes more fully, figures the frustration of an exile community which continues to view its residence in Mexico as a temporary necessity. La última hora del uiltimo dia tracks minutely the Catalans' participation in the arc of this fatally flawed attempt to regain control of history. In this connection, Max Aub's satirical short story, "La verdadera historia de la muerte de Francisco Franco," resonates with the wealthy Catalan plantation owners' engagement in the hyperbolic assassination scheme, a "complot de la izquierda internacional," masterminded by others (209). Aub imagines a waiter in a café in Mexico City where Spanish exiles gather to rehash-incessantly and repetitively - the battles of the war and the future of Spain. He becomes so frustrated with this intrusion into his private space that he decides to assassinate Franco himself as the only way to regain his tranquil existence. Improbably, he succeeds and returns to Mexico City, only to discover that a new generation of Spanish exiles has invaded his café, exhibiting all the intolerable traits of the anti-Franco exiles. In Soler's version of the requisite exile fantasy, the irony falls on Arcadi's lingering attachment to his wartime communist affiliation and the resurrection of bonds forged in postwar France. Arcadi's loss of an arm in the precipitate explosion of a test bomb further figures the self-mutilation that opposition to Franco exacts from those who attempt to recover their lost country and rewrite history. Aub's whimsically ironic tale of a humble waiter carrying out what all the Spanish exiles together have failed to achieve, only to be undone by the latest invasion of proFranco exiles, yields to Soler's more unsettling vision of international agents provocateurs acting on their own agendas and sponging off the exiles' wealth and agonizing aspirations for political change.

In conclusion, Catalan culture represented itself at the Frankfurt Book Fair as embracing all geographical territories where the Catalan language-broadly defined-is spoken and used in literary expression: the Autonomous Communities of Catalonia, Valencia, and the Balearic Islands, and outside the Iberian peninsula the Roussillon and Alghero in Sardinia. Jordi Soler's two novels suggest La Portuguesa as 
an additional space that meets these criteria, albeit within a more limited timeframe. From 1946 onward, although shrunk to one last survivor at the end of the second novel, La Portuguesa remains a Catalan-speaking enclave and a bastion of iconic Catalan culture. "In an interview, Soler contended that the only immutable markers of Catalan identity for the inhabitants of $\mathrm{La}$ Portuguesa, "que no se pueden cambiar," were "las canciones de Serrat... y los resultados del Barça, que son como son y nadie los puede cambiar" (Díaz de Tuesta). Recently the Barça president, Joan Laporta, following surely unknowingly in the footsteps of the inhabitants of La Portuguesa, provocatively posited the specter of the football club as nation when he somewhat humorously warned that by 2020 , "'si no hemos conseguido los objetivos que muchos catalanes queremos, espero que no tengamos que proclamar la República Catalana del Barça'” (Cuadrado "Laporta"). The narrator of La última bora del último día returns to Catalonia, as did Soler, completing his family's geographical circle by settling in Barcelona and carrying with him as cultural baggage the Catalan language as spoken in La Portuguesa and Arcadi's Catalan historical memory. When the narrator of Los rojos de ultramar speaks to the Complutense students, it is the Mexican anthropologist's Catalan name that arouses their curiosity. As Quim Monzó warned, people tend to confuse language with geography. Thus Soler's two novels raise the possibility that La Portuguesa belongs on the map of regions where the Catalan language and culture and, more especially, Catalan literature flourish. Their narrator(s) live enmeshed in Catalan culture in a Catalan-speaking environment. Like his narrator, Jordi Soler is arguably a Catalan author, despite writing in Castilian. Carme Riera convincingly makes this case when she identifies authors who are "catalanes por nacimiento o por empadronamiento" and adduces that their books "contribuyen a la vitalidad de la literatura en castellano desde tierras catalanas. Una prueba más de la buena salud de la lengua castellana en Cataluña... " ${ }^{\prime 25}$ ). Likewise she notes that "[p]ese a no haber nacido en Cataluña," certain renowned Spanishlanguage poets and novelists "sí viven y escriben en Barcelona desde hace años... [;] en consecuencia, pueden considerarse catalanes" (25). ${ }^{12}$ Soler, in his childhood "disfressat de nen del carrer Muntaner," may be a more recent transplant to Barcelona than Riera's examples, having native."

II. The last survivor in La Portuguesa of the original five founders, Bages, has "gone

12. Discussing the poets of the Escuela de Bareelona, Riera acknowledges "sus tics de clase-se trata de señoritos de nacimiento" (24). This assessment speaks also to the privileged position enjoyed by the children born in La Portuguesa whose separateness and difference from those around them resonates throughout Soler's novels. 
moved there in 2002, but like his narrator he speaks Catalan and, closing another circle, claims to live on Muntaner Street (Piquer). ${ }^{13}$ More to the point, he affirms that he writes in Castilian by choice..$^{1 / 4}$ The rhetorical question Vidal-Folch poses in "Taxonomistas de las mariposas" suggests the possibility of reading not only Soler's narrator but Soler himself as Catalans. Citing literary examples, Vidal-Folch queries: "¿Es personaje catalán el Pijoaparte y no es, tanto como castellana, literatura catalana Últimas tardes con Teresa, y no es literato catalán su autor, Juan Marsé?" As the Frankfurt Book Fair demonstrated, Josep Bargalló and the Institut Ramon Llull disagree: "La cultura es un concepto de territorio, por eso en el programa artístico hemos incluido cultura en castellano; pero la literatura no es un concepto territorial sino lingüístico" (Cuadrado "Bargalló"). The tack they take by equating literature with language excludes the Catalan-speaking territory of La Portuguesa, since it does not produce literature written in Catalan. ${ }^{15}$ Unless, however, another assertion by Bargalló leaves open the possibility of including La Portuguesa and the literature it spawned: "En esta feria se trata de mostrar la literatura que nos singulariza como catalanes, la que nos es propia y que une los diversos territorios de lengua catalana." Smaller even than Alghero and founded less than a century ago, La Portuguesa, "la Cataluña de ultramar" (Mora), may be one more historical redoubt of the Catalan language, one that survives as a uniquely imagined linguistic, cultural and historical narrative world immortalized in literature.

MARYELLEN BIEDER INDIANA UNIVERSITY

13. In interviews Soler emphasizes the literal circularity of his recent return to his grandfather's Barcelona and affirms that he lives "en la misma calle en que nació su madre" (Pérez Andújar).

14. Elsewhere Soler categorizes himself as "un escritor 'medio catalán que escribe en castellano" (EFE).

15. There is a Catalan translation of La última bora del último día (Barcelona: Magrana, 2007) which Eva Piquer finds disappointing: "es perden matisos lingüistics i estilístics, però vaja, benvinguda sigui." 


\section{WORKS CITED}

Amat, Nuria. "El circo patriótico." El País 16 Oct. $2007: 17$.

AUB, Max. "La verdadera historia de la muerte de Francisco Franco."

La verdadera bistoria de la muerte de Francisco Franco y otros cuentos. Mexico: Libro Mex, 1960. 9-32.

BARGALLÓ, Josep. Interview with Carles Geli. "A Francfort le va la polémica." El País 9 Oct. 2007: 50.

BarranCo, Justo. "Un gran libro abierto: De Llull a la industria de hoy, Frankfurt expone la historia editorial catalana." La Vanguardia 10 Oct. 2007: 44.

CUADRADO, Nùria. "Bargalló traza un balance triunfalista." El Mundo I4 Oct. 2007: 56.

-. "Laporta amenaza con crear la 'República Catalana del Barça." El Mundo II Oct. 2007: 54.

DEMiCHeLI, Tulio. "Jordi Soler: 'Mi abuelo sintió que Franco le había vencido dos veces."” $A B$ C.es. Io Nov, ro07. <http://www.abc.es/ hemeroteca.historico-IO-II-2007/abc/Cultura/jordi_soler>

DiAZ DE TUESTA, María José. "Entrevista: Jordi Soler, escritor: 'El fútbol era el limbo del exiliado." El País 29 Oct. 2007. <http://elpais. com/article/cultura/futbol/era/limbo/exiliado/elpepicul/20071029 elpepicul_A/Tes>

EFE. "Escritor Jordi Soler narra 'el exilio dentro del exilio' de catalanes en la selva mexicana." <http://www.tercera.cl/medio/articulo/o,0,3255_5700_304963166,00.html>

HIRSCH, Marianne. Family Frames: Photography, Narrative, and Postmemory. Cambridge: Harvard UP, 1997.

LABANYI, Jo. "Memory and Modernity in Democratic Spain: The Difficulty of Coming to Terms with the Spanish Civil War." Poetics Today 28:I (2007): 89-II6.

MARCO, Joaquín. "La última hora del día." El Mundo. El Cultural i8 Oct, 2007: I5.

MONZÓ, Quim. "El discurso de presentación de la cultura catalana: 'Una base de la cultura europea."' La Vanguardia ro Oct. 2007: 46. MORA, Rosa. "Los nietos de la guerra también somos mutilados": Entrevista: Jordi Soler escritor." El Pais 6 Oct. 2005. <http://www. nodo50.org/foroporlamemoria/documentos/2005/jordi_soler>

PÉREZ ANDÚJAR, Javier. "Text d'autor: A la sombra de los muchachos rojos." El Pais 20 April 2005. <http://e-barcelona.org index.php? name $=$ News $\&$ file $=$ article $\&$ sid $=6265>$

PIQUeR, Eva. "El nen de la selva." Avui 28 Oct. 2007. <http://paper. avui.cat/article/cultura/103853/nen/la/selva/html>

RESINA, Joan Ramon. "'Barcelona ha entrat en crisi." Vilaweb 2r Nov. 2007. http://www.vilaweb.cat/www/noticia?p_idemp $=263666 \mathrm{r}>$ 
RIERA, Carme. "Un imaginario bilingüe: Los puntos entre dos lenguas." El Pais. Babelia 6 Oct. 2007: 24-25.

SANCHIS, Ima. "En aquella selva se hablaba un catalán mestizo." $\mathrm{La}$ Vanguardia Is Oct. 2007: 88.

SANTANA, Mario. "National Literatures and Interliterary Communities in Spain and Catalonia." Catalan Review I4 (2000): 159-71.

SOLER, Jordi. Los rojos de ultra mar. 2004. $2^{\text {nd }}$ ed. Madrid: Santillana Ediciones, 2005.

-. La última hora del último día. Barcelona: RBA Libros, 2007.

VALLE-INCLAN, Ramón María del. "Juventud militante: Autobiografías." Alma Española 1.8 (1903): 7.

VIDAL-FOLCH, Xavier. "Feria del Libro de Francfort: Taxonomistas de las mariposas." El País I4 Oct. 2007: 47. 